\title{
Heat stress affects some physiological and productive variables and alters metabolism in dairy ewes
}

\author{
Nabil Mehaba, * (1) Wellington Coloma-Garcia,† (i) Xavier Such, (1) Gerardo Caja, (1) and Ahmed A. K. Salamał (1) \\ Group of Research in Ruminants (G2R), Department of Animal and Food Sciences, Universitat Autònoma de Barcelona, 08193 Bellaterra, \\ Barcelona, Spain
}

\begin{abstract}
Heat stress (HS) has a significant economic impact on the global dairy industry. However, the mechanisms by which HS negatively affects metabolism and milk synthesis in dairy ewes are not well defined. This study evaluated the production and metabolic variables in dairy ewes under controlled HS conditions. Eight Lacaune ewes $(75.5 \pm 3.2 \mathrm{~kg}$ of body weight; $165 \pm$ $4 \mathrm{~d}$ of lactation; $2.31 \pm 0.04 \mathrm{~kg}$ of milk per day) were submitted to thermoneutral (TN) or HS conditions in a crossover design (2 periods, $21 \mathrm{~d}$ each, 6 -d transition). Conditions (day-night, 12-12 h; relative humidity; temperature-humidity index, THI) were: $\mathrm{TN}\left(15-20^{\circ} \mathrm{C} ; 50\right.$ $\pm 5 \%$; THI $=59-65)$ and $\mathrm{HS}\left(28-35^{\circ} \mathrm{C} ; 45 \pm 5 \%\right.$; THI $=75-83)$. Ewes were fed ad libitum and milked twice daily. Rectal temperature, respiratory rate, feed intake, water consumption, and milk yield were recorded daily. Milk and blood samples were collected weekly. Additionally, TN and HS ewes were exposed to glucose tolerance test, insulin tolerance test, and epinephrine challenge. Heat stress reduced feed intake $(-11 \%)$, and increased rectal temperature $\left(+0.77^{\circ} \mathrm{C}\right)$, respiratory rate $(+90$ breaths $/ \mathrm{min})$, and water consumption $(+28 \%)$. Despite the reduced feed intake, HS ewes produced similar milk to TN ewes, but their milk contained lower fat $(-1.7$ points) and protein ( -0.86 points). Further, HS milk tended to contain more somatic cells $(+0.23 \mathrm{log}$ points). Blood creatinine was greater in HS compared with TN, but no differences in blood glucose, nonesterified fatty acids, or urea were detected. When glucose was infused, TN and HS had similar insulin response, but higher glucose response $(+85 \%)$ was detected in HS ewes. Epinephrine infusion resulted in lower nonesterified fatty acids response $(-215 \%)$ in HS than TN ewes. Overall,

Received May 22, 2020.

Accepted August 20, 2020.

*Current address: Tests and Trials Ltd., Ignacio Luzán, 24, 22400, Monzón, Huesca, Spain

†Current address: Facultad de Medicina Veterinaria, Universidad Agraria del Ecuador (UAE), Guayaquil, Ecuador

$\ddagger$ Corresponding author: ahmed.salama@uab.cat
\end{abstract}

HS decreased feed intake, but milk production was not affected. Heat stress caused metabolic adaptations that included increased body muscle degradation and reduced adipose tissue mobilization. These adaptations allowed ewes to spare glucose and to avoid reductions in milk yield.

Key words: milk production, metabolism, heat stress, dairy ewes

\section{INTRODUCTION}

Sheep production is one of the most important agricultural activities in the Mediterranean area and several regions in the world. The European Mediterranean countries account for more than $13 \%$ of the world sheep population, and $28 \%$ of the global dairy sheep production is concentrated in this region (FAO, 2018). Sheep milk is mainly used for cheese production, and alterations in milk yield or milk quality will affect cheese yield. Predictions relative to climate change effects consider the Mediterranean basin as one of the regions where larger increases in temperatures are expected (Pasqui and Di Giuseppe, 2019).

The sheep thermoneutral zone is claimed to be between 5 and $25^{\circ} \mathrm{C}$ (Curtis, 1983). Another study on the relationship between production traits and climatic variables indicated a comfort zone between 11 and $21^{\circ} \mathrm{C}$ of average daily temperature (Ramón et al., 2016). Heat stress (HS) negatively affects milk yield and its components in Holstein dairy cows (Baumgard et al., 2011) and Murciano-Granadina dairy goats (Salama et al., 2014). With regard to dairy sheep, most of the available studies evaluated the effect of HS on milk production between seasons (Finocchiaro et al., 2005; Peana et al., 2007; Ramón et al., 2016). These studies detected reductions in milk yield and milk components during summer. However, in studies comparing seasons, the effect of HS was often confounded with that of different feeding patterns across seasons. To the best of our knowledge, no published studies have evaluated the detailed responses of lactating dairy ewes to HS under controlled climatic and feeding conditions. 
With regard to metabolism under HS, available results in dairy cows (Wheelock et al., 2010; Baumgard et al., 2011) and goats (Hamzaoui et al., 2013; Salama et al., 2014; Mehaba et al., 2019) indicate homeorhetic adaptations to suppress lipid mobilization, despite reduced feed intake and increased maintenance requirements. Studies comparing heat-stressed and thermoneutral pair-fed cows showed that the lack of body lipid mobilization induced by HS is because of greater blood insulin accompanied by changes in the expression of gluconeogenic genes in liver (Wheelock et al., 2010; Baumgard et al., 2011). Furthermore, heat-stressed dairy cows (Baumgard and Rhoads, 2013) and goats (Salama et al., 2014; Mehaba et al., 2019) experience increased protein catabolism, and some of these mobilized AA could be used for glucose synthesis. Whether similar metabolic changes occur in heat-stressed lactating dairy ewes is not known.

The identification of HS animals and the understanding of the physiological mechanisms by which HS reduces milk production are critical for developing novel approaches to minimize production losses during HS conditions. Furthermore, little attention has been paid to comprehensively evaluate the productive and metabolic responses to HS in lactating dairy ewes. Therefore, the objectives of the present study were to evaluate the effect of HS on productive variables (milk yield and milk composition) and to measure the metabolic and physiological responses of dairy ewes to HS under controlled climatic chamber conditions.

\section{MATERIALS AND METHODS}

\section{Animals, Treatments, and Management Conditions}

Animal care conditions and management practices were approved by the Ethical Committee of Animal and Human Experimentation of the Universitat Autònoma de Barcelona (ref. 3142), following procedures described in the Spanish and EU legislations (R.D. 53/2013, and Council Directive 2010/63/EU).

Eight multiparous lactating Lacaune dairy ewes (75.5 $\pm 3.2 \mathrm{~kg}$ of BW; $165 \pm 4$ DIM; $2.31 \pm 0.04 \mathrm{~L} / \mathrm{d}$ of milk yield) with healthy and symmetrical udders were used. Animals were allocated individually in $1.62 \mathrm{~m}^{2}$-pens $(1.8 \times 0.90 \mathrm{~m})$ with separate feed and water throughout the experiment. Ewes were blocked in 2 balanced groups according to milk yield and milk composition. The experimental design was a crossover with 2 periods of $21 \mathrm{~d}$ each, and 2 climatic treatments that differed in the temperature-humidity index (THI) values. With the aim to have the same wool length in all animals, ewes were shorn before the beginning of the experiment to have $2-\mathrm{cm}$ long fleece.
Ewes were adapted to the experimental conditions for 14 d. Afterward, ewe groups were randomly assigned to 2 treatments: thermoneutral conditions $(\mathbf{T N}$; $15-20^{\circ} \mathrm{C}, 50 \pm 5 \%$ relative humidity, $\left.\mathrm{THI}=59-65\right)$ or HS (12-h day at $35^{\circ} \mathrm{C}$ and $45 \pm 5 \%$ relative humidity; $\mathrm{THI}=83$; and 12 -h night at $28^{\circ} \mathrm{C}$ and $45 \pm 5 \%$ relative humidity; THI = 75). After the first period, $6 \mathrm{~d}$ of transition was allowed, during which all ewes remained at TN conditions. Ewes were switched to the opposite treatment in the second period. Photoperiod was $12-\mathrm{h}$ light (0800-2000 h) and 12-h dark (2000-0800 h). The THI were calculated according to NRC (1971).

Throughout the experiment (February-May), the ambient temperature of $\mathrm{TN}$ ewes was maintained at 15 to $20^{\circ} \mathrm{C}$ with the help of an electric heater equipped with a thermostat $(3.5 \mathrm{~kW}$; General Electric, Barcelona, Spain) when needed. The HS ewes were kept in a $4 \times 6$ $\times 2.3$-m climatic chamber as described by Hamzaoui et al. (2013). Ewes were machine-milked twice daily (0800 and $1700 \mathrm{~h}$ ). All TN and HS ewes were individually fed ad libitum a TMR (Table 1) once daily (0900 h), and orts were recorded daily. The diet was formulated to meet or exceed the predicted requirements (INRA, 2018) of energy, protein, minerals, and vitamins. Clean water was permanently available at ambient temperature.

\section{Sampling, Measurements, and Analyses}

Rectal temperature (RT) and respiratory rate $(\mathbf{R R})$ were registered 3 times daily $(0800,1200$, and $1700 \mathrm{~h})$. The RR was determined by counting flank movements for $12 \mathrm{~s}$ and multiplying by 5 . The RT was measured using a digital thermometer (Accu-vet, ST714AC, Tecnovet S.L, Barcelona, Spain; reading range $32.0-42.0^{\circ} \mathrm{C}$ and accuracy $\pm 0.10^{\circ} \mathrm{C}$ ).

Feed intake and water consumption were measured daily throughout the experiment. Feed samples were collected before the beginning of each experimental period and were analyzed for $\mathrm{DM}, \mathrm{ADF}, \mathrm{NDF}, \mathrm{CP}$, and ash contents according to AOAC International (2003). The chemical composition and nutritive value of ration ingredients are shown in Table 1.

Ewes were weighed weekly using an electronic scale (Tru-test A6500, Auckland, New Zealand) on 2 consecutive days after milking and before feeding. The net energy balance was calculated using the following equation: energy balance $=$ net energy intake $-\left(\mathrm{NE}_{\mathrm{M}}\right.$ $\left.+\mathrm{NE}_{\mathrm{L}}\right)$. The $\mathrm{NE}_{\mathrm{M}}$ was calculated using the following equation: $\mathrm{NE}_{\mathrm{M}}=\left(0.0345 \times \mathrm{BW}^{0.75}\right)$ according to INRA, (2018). Maintenance costs were increased by $30 \%$ for HS ewes as recommended (NRC, 2001). The $\mathrm{NE}_{\mathrm{L}}$ was calculated by using the following equation: $\mathrm{NE}_{\mathrm{L}}=$ 
$[0.2224+0.0071$ (fat, $\mathrm{g} / \mathrm{kg})+0.0043 \times$ (protein, g/ $\mathrm{kg})] \times 0.686 \times$ milk yield $(\mathrm{INRA}, 2018)$.

Milk yield at each milking was weighed by electronic scale (Mobba industrial, Barcelona, Spain) and registered daily. Milk samples at each milking were collected twice per week. Milk samples were analyzed for fat, protein $(\mathrm{N} \times 6.38)$, lactose, and $\mathrm{SCC}$ as previously described (Mehaba et al., 2019). A milk aliquot was stored at $-20^{\circ} \mathrm{C}$ to determine milk osmolality using a Fiske 110 osmometer (Fiske Associations, Norwood, MA).

Two 10-mL blood samples were collected at $0800 \mathrm{~h}$ (before milking and feeding) from the jugular vein using heparinized and $\mathrm{K}_{2}$-EDTA vacutainer tubes (BD, Belliver Industrial Estate, Plymouth, UK) at d 3, 10, and 17 of each period. Plasma was obtained by centrifugation at $2,000 \times g$ for $15 \mathrm{~min}$ at $4^{\circ} \mathrm{C}$ and stored

Table 1. Ingredients, chemical composition, and nutritive value of the TMR offered to the dairy ewes

\begin{tabular}{|c|c|}
\hline Item & Value \\
\hline \multicolumn{2}{|l|}{ Ingredients, $\%$ as fed } \\
\hline Alfalfa hay & 60.0 \\
\hline Cracked oat grain & 2.0 \\
\hline Cracked corn grain & 1.6 \\
\hline Brewing barley & 4.0 \\
\hline Soybean hull & 18.0 \\
\hline Soybean meal, $44 \%$ & 2.0 \\
\hline Rapeseed meal & 4.0 \\
\hline Corn gluten feed & 4.0 \\
\hline Soybean oil & 2.0 \\
\hline Cane molasses & 0.8 \\
\hline Salt $(\mathrm{NaCl})$ & 0.2 \\
\hline Vitamin and mineral complex for goats & 0.4 \\
\hline Dicalcium phosphate & 1.0 \\
\hline \multicolumn{2}{|l|}{ Chemical composition, \% of DM } \\
\hline DM & 87.9 \\
\hline $\mathrm{OM}$ & 87.8 \\
\hline $\mathrm{CP}$ & 17.0 \\
\hline Ether extract & 3.73 \\
\hline $\mathrm{NDF}$ & 26.5 \\
\hline $\mathrm{ADF}$ & 17.6 \\
\hline ADL & 3.02 \\
\hline \multicolumn{2}{|l|}{ Nutritive value $^{1}$} \\
\hline $\mathrm{UFL}_{2}^{2} / \mathrm{kg}$ & 0.92 \\
\hline $\mathrm{NE}_{\mathrm{L}},{ }^{3} \mathrm{Mcal} / \mathrm{kg}$ & 1.62 \\
\hline $\mathrm{PDI},{ }^{4} \mathrm{~g} / \mathrm{kg}$ & 91.2 \\
\hline $\mathrm{PDIA}^{,} \mathrm{g} / \mathrm{kg}$ & 42.8 \\
\hline $\mathrm{RPB}^{6} \mathrm{~g} / \mathrm{kg}$ & 34.3 \\
\hline Absorbable $\mathrm{Ca}, \mathrm{g} / \mathrm{kg}$ & 3.04 \\
\hline Absorbable $\mathrm{P}, \mathrm{g} / \mathrm{kg}$ & 5.38 \\
\hline
\end{tabular}

${ }^{1}$ Calculated according to Institut National de la Recherche Agronomique (INRA, 2018).

${ }^{2}$ Feed units for lactation.

${ }^{3} 1 \mathrm{UFL}=1.7 \mathrm{Mcal}$ of $\mathrm{NE}_{\mathrm{L}}$.

${ }^{4}$ Protein digested in the small intestine from food and microbial synthesis origins.

${ }^{5}$ Protein digested in the small intestine supplied by food rumen undegradable protein.

${ }^{6}$ Rumen protein balance; represents RUP, microbial protein, and endogenous protein. at $-20^{\circ} \mathrm{C}$ until the analyses of glucose, nonesterified fatty acids (NEFA), BHB, cholesterol, and albumin (Mehaba et al., 2019). Additional blood samples (approximately $0.3 \mathrm{~mL}$ ) were collected and immediately applied to disposable cartridges (i-STAT CHEM8+; Abbott Point of Care Inc., Princeton, NJ). Then, the cartridge was inserted into an i-STAT hand-held analyzer, and the results of glucose, BUN, creatinine, hematocrit, hemoglobin, $\mathrm{Cl}, \mathrm{Na}, \mathrm{K}$, Ca ions, total $\mathrm{CO}_{2}$ concentration, and anion gap were obtained.

On d 15 of the second period, each ewe was fitted with indwelling jugular silicone rubber catheters $\mathrm{CNu}$ tricath Silicone, $60 \mathrm{~cm}$ length and 14-gauge, Vygon, Valencia, Spain). On d 17, 19, and 21, glucose tolerance test (GTT; $0.25 \mathrm{~g} / \mathrm{kg}$ of BW), insulin tolerance test $(4.6 \mu \mathrm{g} / \mathrm{kg}$ of $\mathrm{BW})$, and epinephrine challenge (2 $\mu \mathrm{g} / \mathrm{kg}$ of BW) were performed, respectively. Dextrose (D9434, Sigma-Aldrich, St. Louis, MO), insulin (bovine insulin form pancreas, I6634, Sigma-Aldrich), and epinephrine (E4250, Sigma-Aldrich) were diluted in sterile $0.9 \% \mathrm{NaCl}$ solution (Vitulia 0.9\%, Laboratorios ERN S.A., Barcelona, Spain). All solutions were sterilized by filtration through $0.22-\mu \mathrm{m}$ polyether-sulfone filters (Millex-GP, Millipore; Merck Life Science SLU, Madrid, Spain) using 1 filter for each $200 \mathrm{~mL}$ of solution and kept at $4^{\circ} \mathrm{C}$.

On the day of each metabolic test, 3 prechallenge blood samples $(-20,-10,0 \mathrm{~min})$ were collected followed by an intravenous bolus dose of the corresponding metabolite. Thereafter, blood samples were collected at 5, 10, 20, 30, 45, 60, 90, and 120 min. After each blood sampling, the catheters were flushed with heparinized $0.9 \%$ saline solution (500 IU/mL; Clexane $4000 \mathrm{UI}$, Sanofi Aventis, Paris, France). Plasma was harvested by centrifugation for $15 \mathrm{~min}$ at $2,000 \times g$ at $4^{\circ} \mathrm{C}$ and stored at $-20^{\circ} \mathrm{C}$ until further analysis. Plasma insulin concentration was analyzed by ELISA immunoassay sandwich type for quantitative determination of ovine insulin in plasma (Mercodia, Diagnostics, Uppsala, Sweden). Glucose was analyzed by the hexokinase method (OSR 6121, Reagent System Olympus, Beckman Coulter, Krefeld, Ireland). Values of NEFA and BHB were determined as indicated by Mehaba et al. (2019).

The area under the curve (AUC) of metabolite responses to GTT, insulin tolerance test, and epinephrine challenge were calculated by the trapezoidal method after the correction for the baseline values. Plasma baseline data were obtained by averaging the corresponding values at $\min -20,-10$ and 0 . Values of peaks or nadirs of each metabolite after infusions were recorded. Glucose clearance rate and glucose half-life during the GTT were calculated according to Kerestes et al. (2009). For insulin tolerance test, insulin-stimulated 
Table 2. Rectal temperature, respiratory rate, feed intake, BW, and milk production variables of dairy ewes under thermoneutral $(\mathrm{TN} ; \mathrm{n}=8)$ or heat stress (HS; $\mathrm{n}=8$ ) conditions; values are least squares means and SEM

\begin{tabular}{|c|c|c|c|c|c|c|}
\hline \multirow[b]{2}{*}{ Item } & \multirow[b]{2}{*}{$\mathrm{TN}$} & \multirow[b]{2}{*}{ HS } & \multirow[b]{2}{*}{ SEM } & \multicolumn{3}{|c|}{$P$-value } \\
\hline & & & & Treatment & Period & Treatment $\times$ period $^{1}$ \\
\hline Respiratory rate, breaths/min & 42 & 132 & 2 & 0.001 & 0.725 & 0.367 \\
\hline DMI, kg/d & 2.69 & 2.39 & 0.08 & 0.019 & 0.001 & 0.812 \\
\hline Water consumption, L/d & 7.14 & 9.14 & 0.31 & 0.001 & 0.003 & 0.159 \\
\hline BW change, $\mathrm{kg} / 21 \mathrm{~d}$ & 4.50 & -0.38 & 0.41 & 0.002 & 0.226 & 0.729 \\
\hline Energy balance, ${ }^{3}$ UFL/d & 0.45 & -0.03 & 0.09 & 0.003 & 0.005 & 0.886 \\
\hline \multicolumn{7}{|l|}{ Milk composition } \\
\hline Fat, \% & 6.81 & 5.74 & 0.13 & 0.001 & 0.980 & 0.180 \\
\hline Protein, \% & 6.37 & 5.51 & 0.13 & 0.001 & 0.177 & 0.049 \\
\hline Lactose, \% & 4.43 & 4.74 & 0.09 & 0.028 & 0.427 & 0.184 \\
\hline Fat:protein ratio & 1.07 & 1.05 & 0.03 & 0.539 & 0.643 & 0.274 \\
\hline $\mathrm{SCC}, \log 10 / \mathrm{mL}$ & 4.40 & 4.63 & 0.08 & 0.066 & 0.125 & 0.679 \\
\hline
\end{tabular}

${ }^{1}$ Interaction of treatment $\times$ period.

${ }^{2} \mathrm{FCM}_{6.5 \%}=$ kilogram of milk yield $\times(0.37+0.09 \times$ fat $\%)$ according to Pulina et al. $(2005)$.

${ }^{3}$ Energy balance $=$ energy intake $-\left(0.0345 \times \mathrm{BW}^{0.75}\right)+[0.686 \times$ milk yield, $\mathrm{L} \times(0.0071 \times$ fat, $\mathrm{g} / \mathrm{L}+0.0043 \times \mathrm{protein}, \mathrm{g} / \mathrm{L}+0.2224)]$ according to INRA (2018). UFL = feed units for lactation.

blood glucose response was calculated as indicated by Kerestes et al. (2009).

\section{Statistical Analyses}

Data were analyzed by the MIXED procedure for repeated measurements of SAS version 9.4 (SAS Institute Inc., Cary, NC). The statistical mixed model contained the effects of environmental conditions (TN and HS), period (1 and 2), sampling time, and interactions of environmental conditions $\times$ period, environmental conditions $\times$ sampling time, and period $\times$ sampling time as fixed effects, as well as the random effects of the animal and the residual error. For the data of RT and RR measured at 0900, 1200, and $1700 \mathrm{~h}$, a fixed factor of the hour of day was added to the model. Data of performances (i.e., DMI, water consumption, and milk yield) and physiological indicators (i.e., RT and $\mathrm{RR}$ ) were analyzed on a weekly basis. For the basal levels of physiological challenge variables, $t$-tests for independent means were used. Differences between least squares means were determined with the PDIFF option of SAS.

\section{RESULTS AND DISCUSSION}

\section{Rectal Temperature and RR}

The RT was greater $\left(+0.77^{\circ} \mathrm{C}\right.$ on average; $\left.P<0.001\right)$ in HS than TN ewes (Table 2). Furthermore, RT in- creased $(P<0.05)$ in $\mathrm{HS}$ ewes from $39.38^{\circ} \mathrm{C}$ at 0800 $\mathrm{h}$ to $39.85^{\circ} \mathrm{C}$ at $1700 \mathrm{~h}$ in accordance with increment in the ambient temperature from $28^{\circ} \mathrm{C}$ during night to $35^{\circ} \mathrm{C}$ during the day. However, RT did not vary between 0800 and $1700 \mathrm{~h}$ in TN ewes. Heat-stressed ewes had $214 \%$ increase in RR $(+90$ breaths $/$ min; $P<0.001)$ on average compared with that for TN ewes. The HS ewes increased $(P<0.05) \mathrm{RR}$ by $34 \%$ in the evening (154 breaths/min) compared with that for the morning measurement values (115 breaths/min). The increased $\mathrm{RR}$ in HS ewes was to dissipate heat, as $\sim 65 \%$ of body heat is lost through the respiratory tract in sheep under hyperthermia (Hales and Brown, 1974). Our ewes were shorn before the experiment (2-cm fleece length), and some heat dissipation by sweating could have occurred in addition to evaporation by panting.

\section{Feed Intake and BW Change}

The DMI decreased $(P<0.001)$ in HS ewes by $11 \%$ throughout the experiment (Table 2). This lower DMI induced a slight negative energy balance in HS compared with TN ewes (Table 2). Reduction in appetite under HS is primarily a result of the elevated body temperature. The reduced DMI may be also related to an increase in gut fill as a result of an increase in water consumption (Silanikove, 1992). The rumen seems to serve as a water reservoir during high heat load (Silanikove, 1992). The decrease in DMI observed in our HS 
ewes was lower than reported in Holstein dairy cows (-30\%; Wheelock et al., 2010) and Murciano-Granadina goats ( $-21 \%$; Hamzaoui et al., 2013) that were heat-stressed to a similar extent as in the present study. In addition, our HS ewes did not experience significant milk yield losses (discussed later). Consequently, it seems that dairy ewes experience less productive losses under HS conditions compared with dairy cows and goats. This assumption should be confirmed by carrying out comparative studies using animals from the different species at similar stage of lactation and feeding conditions. The HS ewes had greater water consumption compared with TN ewes $(+2.0 \mathrm{~L} / \mathrm{d} ; P<$ $0.001)$. The increase in water consumption in the present study was mainly to meet the increment of water requirements for heat dissipation by evaporation.

The HS ewes lost BW, whereas TN ewes gained weight (Table $2 ; P<0.01$ ). On average, HS ewes lost 18 $\mathrm{g} / \mathrm{d}$, whereas TN ewes gained $214 \mathrm{~g} / \mathrm{d}$. This loss in BW in HS ewes agreed with the slight negative energy balance detected compared with that for TN ewes (Table 2). Under HS conditions, maintenance requirements increased because of the increment in energy expended for heat dissipation and the production of high amounts of heat shock proteins. In addition, HS Holstein cows (Ronchi et al., 1999) and Murciano-Granadina goats (Salama et al., 2014) mobilize muscles and use some AA for gluconeogenesis. Our HS ewes also degraded muscles as indicated by greater blood creatinine levels compared with that for TN ewes (discussed later).

\section{Milk Yield and Milk Composition}

Despite the reduced DMI and increased RT and RR, HS ewes produced similar milk yield and FCM compared with that for TN ewes (Table 2). Our ewes were in their second half of lactation, and milk yield response to HS would have been different if ewes were in an earlier stage of lactation. Abdalla et al. (1993) also reported that crossbred (Finn $\times$ Dorset $\times$ Rambouillet) early-lactating ewes do not suffer milk yield losses under controlled HS conditions (constant $35^{\circ} \mathrm{C}, 55 \%$ relative humidity, $\mathrm{THI}=86$ ). Additionally, Hamzaoui et al. (2013) observed that HS Murciano-Granadina goats in late lactation produce similar milk yield to TN goats under controlled climatic conditions. Nevertheless, in the studies evaluating the effect of HS by comparing among seasons, milk yield of mid-lactating Sarda ewes is reduced by $15 \%$ when maximum ambient temperature is higher than $24^{\circ} \mathrm{C}$ (Peana et al., 2007). Further, late-lactating Comisana ewes experience a reduction in milk yield at temperatures $>35^{\circ} \mathrm{C}$ (Sevi et al., 2001).
Evaluating the effect of HS by the comparison between seasons includes the inevitable variations related to different feeding and photoperiod conditions, and these variations were not present in our study.

Compared with TN, HS decreased milk fat and protein contents by 13 to $16 \%$, respectively (Table 2 ). Similarly, Abdalla et al. (1993) reported that milk fat and protein contents are depressed by HS in crossbred ewes. In addition, Ramón et al. (2016) reported a reduction in fat and protein yields in Manchega ewes during summer. In the present study, lactose content was higher in HS ewes than in TN ewes $(P<0.05)$ in accordance with the numerical increment in milk yield. Despite the reduced fat and protein contents by HS, fat, protein, and lactose yields were not affected (Table 2 ), which might be caused by the numerical increment in milk yield by HS. Consequently, the mammary synthetic capacity was not impaired by HS in our ewes, which is in contrast to what was recently observed in bovine mammary cells (Salama et al., 2019).

Heat stress tended to increase $(P<0.10)$ milk SCC by $5 \%$ in HS ewes compared with TN ewes. It is not clear why milk SCC increased by HS, but stressful conditions such as a sudden change in milking regimen (Salama et al., 2003) and social isolation (Stelwagen et al., 2000) result in increased milk SCC. The $\log _{10}$ of SCC values in our TN and HS ewes (4.40-4.63) were well below the reported thresholds of mammary inflammation in sheep (5.48-6.00; Murphy et al., 2018). This indicated that the increment of milk SCC in HS ewes was unlikely related to mammary inflammation. In contrast to our results, Caroprese et al. (2011) reported no change in milk SCC in ewes exposed to solar radiation compared with ewes maintained in shade.

Milk osmolality increased $(P<0.001)$ by HS (Table 2 ). Nevertheless, a decreased milk osmolality was observed in heat-stressed goats (Olsson and Dahlborn, 1989) and Friesland ewes (Thompson et al., 1981), which is related to overhydration and hemodilution. Milk osmolality is under strict control, and is isotonic with plasma. Lactose is the major osmotic component of milk, and the increase in milk lactose content in HS ewes might explain the small $(+1 \%)$, albeit significant, increment in milk osmolality. In the current study, values of milk osmolality $(298-302 \mathrm{mOsm} / \mathrm{kg})$ were close to the normal osmolality reported for sheep milk (294 mOsm $/ \mathrm{kg}$; Thompson et al., 1981). Additionally, the treatment $\times$ period interaction was significant, which indicated inconsistent response of milk osmolality to HS throughout periods. All things considered, this makes the detected significant difference in milk osmolality caused by HS marginally relevant. 
Table 3. Blood metabolites of dairy ewes under thermoneutral (TN; $n=8)$ or heat stress $(\mathrm{HS} ; \mathrm{n}=8)$ conditions; values are least squares means and SEM

\begin{tabular}{|c|c|c|c|c|c|c|}
\hline \multirow[b]{2}{*}{ Item } & \multirow[b]{2}{*}{$\mathrm{TN}$} & \multirow[b]{2}{*}{ HS } & \multirow[b]{2}{*}{ SEM } & \multicolumn{3}{|c|}{$P$-value } \\
\hline & & & & Treatment & Period & Treatment $\times$ period $^{1}$ \\
\hline \multicolumn{7}{|l|}{ Acid-base balance } \\
\hline $\mathrm{Na}, \mathrm{mmol} / \mathrm{L}$ & 146.4 & 145.9 & 0.3 & 0.264 & 0.018 & 0.772 \\
\hline $\mathrm{K}, \mathrm{mmol} / \mathrm{L}$ & 4.28 & 4.41 & 0.06 & 0.154 & 0.610 & 0.619 \\
\hline $\mathrm{Ca}, \mathrm{mmol} / \mathrm{L}$ & 1.31 & 1.33 & 0.01 & 0.224 & 0.650 & 0.001 \\
\hline $\mathrm{Cl}, \mathrm{mmol} / \mathrm{L}$ & 105.8 & 107.1 & 0.5 & 0.098 & 0.613 & 0.693 \\
\hline \multicolumn{7}{|l|}{ Energy metabolism } \\
\hline Glucose, g/dL & 60.7 & 58.7 & 1.8 & 0.488 & 0.798 & 0.774 \\
\hline Nonesterified fatty acids, mmol/L & 0.13 & 0.13 & 0.02 & 0.869 & 0.057 & 0.444 \\
\hline $\mathrm{BHB}, \mathrm{mmol} / \mathrm{L}$ & 0.45 & 0.44 & 0.04 & 0.909 & 0.820 & 0.157 \\
\hline Cholesterol, mg/dL & 107 & 99 & 10 & 0.556 & 0.981 & 0.176 \\
\hline Hematocrit, \% PCV & 22.1 & 20.8 & 0.6 & 0.130 & 0.179 & 0.240 \\
\hline Hemoglobin, mmol/L & 7.5 & 7.1 & 0.2 & 0.134 & 0.193 & 0.226 \\
\hline \multicolumn{7}{|l|}{ Protein metabolism } \\
\hline
\end{tabular}

${ }^{1}$ Interaction of treatment $\times$ period.

\section{Blood Metabolites}

There were no differences between treatments in blood electrolytes (Table 3). Nevertheless, HS ewes tended $(P<0.10)$ to have increased blood $\mathrm{Cl}$ concentration compared with that of TN ewes. Usually, high ambient temperatures result in a reduction in blood $\mathrm{Na}, \mathrm{K}, \mathrm{Ca}$ and $\mathrm{P}$, and an increase in $\mathrm{Cl}$ concentrations (Hamzaoui et al., 2013; Mehaba et al., 2019). Similar to our results, HS had no effect on blood $\mathrm{Na}$ and $\mathrm{K}$ concentrations in late-lactating Murciano-Granadina goats, but $\mathrm{Cl}$ levels increased in a previous study (Hamzaoui et al., 2013). Blood total $\mathrm{CO}_{2}$ concentration dropped $(P<0.05)$ by $\mathrm{HS}$ as a result of panting and greater removal of blood $\mathrm{CO}_{2}$.

No differences were observed between TN and HS ewes with regard to blood glucose, cholesterol, NEFA, or BHB values (Table 3). Similarly, heat-stressed latelactating Murciano-Granadina dairy goats (Hamzaoui et al., 2013) and early-lactating crossbred ewes (Abdalla et al., 1993) are able to keep similar blood glucose levels to TN animals. Possible explanations of how HS ewes were able to keep blood glucose values are discussed hereafter. The lack of a NEFA response to HS despite the negative energy balance was also reported in Murciano-Granadina dairy goats (Hamzaoui et al., 2013; Mehaba et al., 2019) and Holstein dairy cows (Baumgard et al., 2011). Nevertheless, Abdalla et al. (1993) detected increased blood NEFA levels in earlylactating crossbred ewes exposed to $35^{\circ} \mathrm{C}$ compared with control ewes at $20^{\circ} \mathrm{C}$. Hemoglobin and hematocrit values did not vary between TN and HS ewes. Similarly, packed cell volume and hemoglobin were unaffected in HS Murciano-Granadina goats (Hamzaoui et al., 2013), although some studies showed increases (Okoruwa, 2014) or decreases (Singh et al., 2016) in HS sheep. Discrepancy among studies could be explained by differences in the species, breed, aptitude (dairy vs. nondairy), stage of lactation, and HS intensity and duration.

Values of BUN and albumin were not affected by HS (Table 3). However, there was an increase $(P<0.001)$ in blood creatinine in HS ewes compared with that for TN ewes, which might indicate muscle degradation. Although our HS dairy ewes experienced lower DMI and had slightly negative energy balance (Table 2), they did not use body fat reserves (no change in blood NEFA as shown in Table 3). However, they mobilized body protein, presumably to use some glucogenic AA for glucose synthesis. Heat-stressed Murciano-Granadina dairy goats also experience increased blood creatinine levels compared with TN animals (Mehaba et al., 2019).

\section{Responses to the Metabolic Tests}

Glucose Tolerance Test. Results of the GTT as an indicator of insulin sensitivity are shown in Figure 1 and Table 4 . The basal glucose levels were not different in TN and HS ewes. Glucose peaked at $5 \mathrm{~min}$ in both treatments, but the peak was greater $(P<0.05)$ in HS $(+511 \%)$ than in TN $(+252 \%)$ ewes (Figure 1a). Blood glucose levels gradually decreased in both treat- 


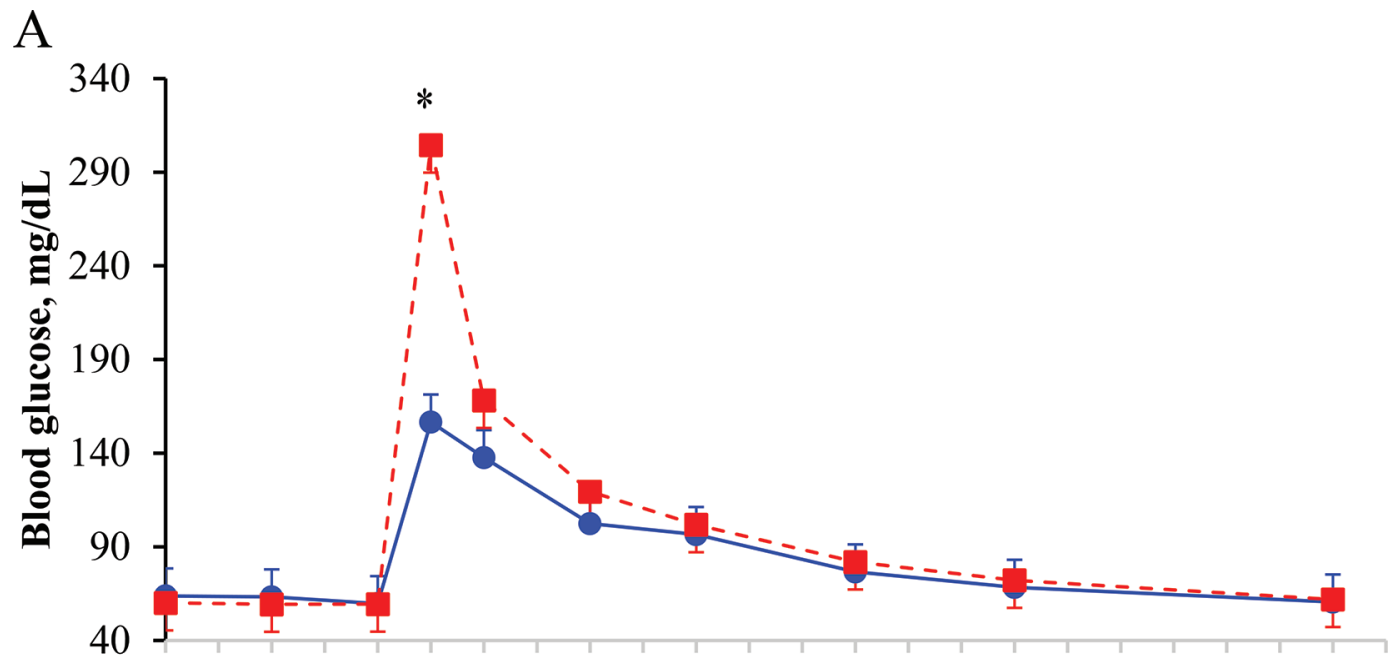

B

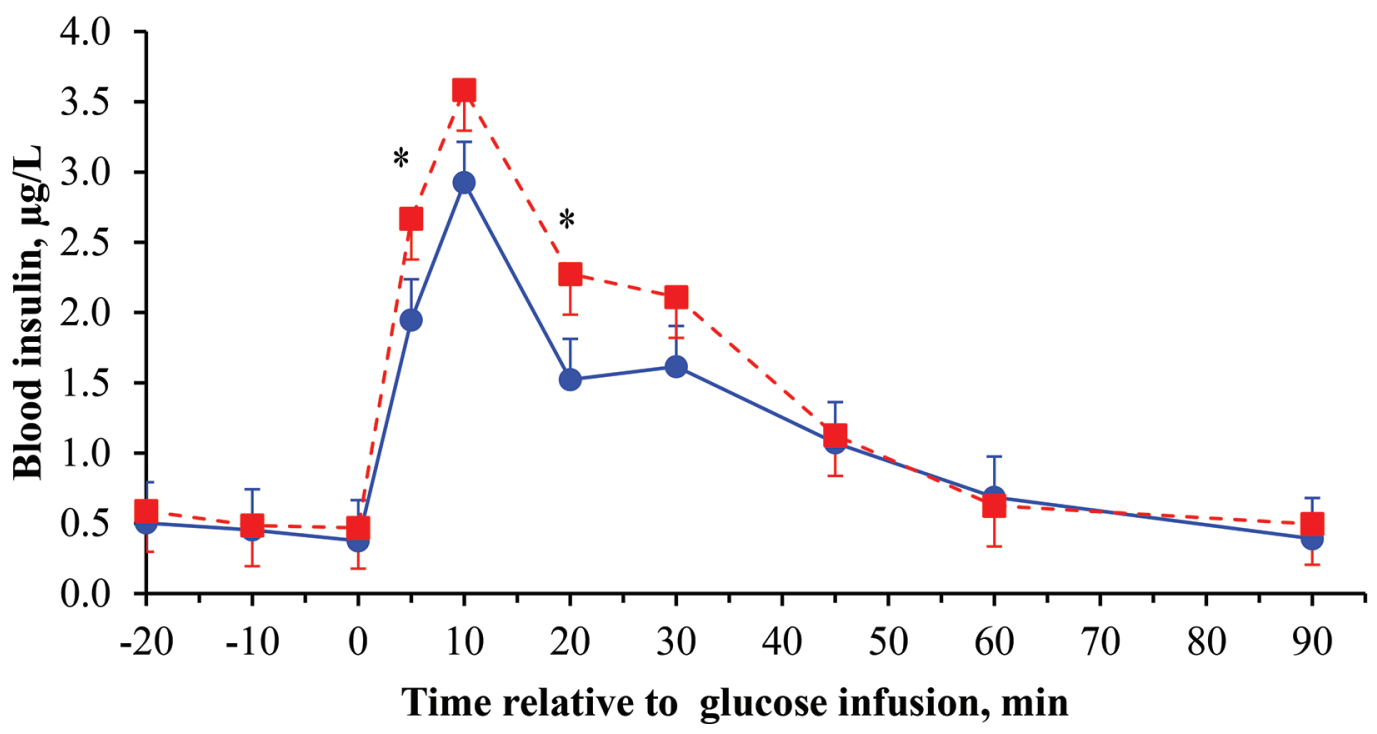

Figure 1. Plasma glucose (A) and insulin (B) response to glucose tolerance test of Lacaune dairy ewes under thermoneutral (TN; blue circles) or heat stress (HS; red squares) conditions. Values are LSM with SEM indicated by vertical bars. ${ }^{*}$ Indicates a difference at $P<0.05$ between TN and HS treatments.

ments and returned to the basal values by 60 min after glucose administration.

Basal plasma insulin values did not differ between TN and HS ewes (Figure 1b; Table 4), although DMI was depressed by HS. Maintaining blood insulin levels during HS is crucial for the activation of the cellular stress response ( $\mathrm{Li}$ et al., 2006). Further, insulin is a potent lipogenic and antilipolytic hormone (Baumgard and Rhoads, 2013). Consequently, maintaining normal insulin levels during HS might explain the absence of significant differences in blood NEFA concentrations between TN and HS ewes (Table 2). As a response to the glucose infusion, plasma insulin levels of both TN and HS ewes peaked at min 10, but no differences in peak values were observed between groups. After the peak, insulin values decreased gradually and reached the basal levels at min 90 . The HS ewes had greater $(P$ $<0.05)$ insulin values than TN ewes only at 5 and 20 min (Figure 1b).

Mean glucose AUC tended $(P<10)$ to be greater at 45 and 90 min in HS ewes compared with TN ewes (Table 4). However, the insulin AUC values did not differ between groups. Wheelock et al. (2010) also found that lactating HS cows have greater glucose response 
Table 4. Metabolite kinetics in response to glucose tolerance test, insulin tolerance test, and epinephrine challenge in dairy ewes under thermoneutral $(\mathrm{TN} ; \mathrm{n}=4)$ or heat stress $(\mathrm{HS} ; \mathrm{n}=4)$; values are least squares means and SEM

\begin{tabular}{|c|c|c|c|c|}
\hline Item & $\mathrm{TN}$ & HS & SEM & $P$-value \\
\hline \multicolumn{5}{|l|}{ Glucose tolerance test } \\
\hline \multicolumn{5}{|l|}{ Glucose } \\
\hline Basal, mg/dL & 62.7 & 59.6 & 1.6 & 0.186 \\
\hline Peak, mg/dL & 94 & 245 & 28 & 0.028 \\
\hline $\mathrm{CR}_{60}, \% / \mathrm{min}$ & 1.7 & 2.9 & 0.2 & 0.010 \\
\hline $\mathrm{AUC}_{45 \min },{ }^{2} \mathrm{mg} / \mathrm{L} \times \min$ & 1,258 & 2,333 & 318 & 0.071 \\
\hline $\mathrm{AUC}_{90 \mathrm{~min}}, \mathrm{mg} / \mathrm{L} \times \min$ & 1,321 & 2,457 & 375 & 0.093 \\
\hline GLU_t $_{1 / 2}$, min & 41.7 & 25.1 & 2.45 & 0.004 \\
\hline \multicolumn{5}{|l|}{ Insulin } \\
\hline Basal, $\mu \mathrm{g} / \mathrm{L}$ & 0.44 & 0.51 & 0.08 & 0.562 \\
\hline Peak, $\mu \mathrm{g} / \mathrm{L}$ & 2.92 & 3.58 & 1.11 & 0.433 \\
\hline $\mathrm{CR}_{60}, \% / \min$ & 3.1 & 3.6 & 0.79 & 0.664 \\
\hline $\mathrm{AUC}_{45 \min }, \mu \mathrm{g} / \mathrm{L} \times \min$ & 32.7 & 44.4 & 18.3 & 0.258 \\
\hline $\mathrm{AUC}_{90 \min }, \mu \mathrm{g} / \mathrm{L} \times \min$ & 35.4 & 46.5 & 5.8 & 0.245 \\
\hline \multicolumn{5}{|l|}{ Insulin tolerance test } \\
\hline \multicolumn{5}{|l|}{ Glucose } \\
\hline Basal, mg/dL & 59.2 & 59.4 & 1.8 & 0.934 \\
\hline Nadir, mg/dL & 31.7 & 34.0 & 2.5 & 0.542 \\
\hline $\mathrm{AUC}_{120 \min } \mathrm{mg} / \mathrm{dL} \times \min$ & -522 & -386 & 87 & 0.313 \\
\hline ISBGR,$\%$ & 0.47 & 0.40 & 0.04 & 0.258 \\
\hline \multicolumn{5}{|l|}{ Nonesterified fatty acids } \\
\hline Basal, $\mathrm{mmol} / \mathrm{L}$ & 0.26 & 0.34 & 0.05 & 0.304 \\
\hline Nadir, mmol/L & 0.19 & 0.15 & 0.05 & 0.242 \\
\hline $\mathrm{AUC}_{120 \min },{ }^{2} \mathrm{mmol} / \mathrm{L} \times \min$ & 1.85 & -1.54 & 0.72 & 0.017 \\
\hline \multicolumn{5}{|l|}{ BHB } \\
\hline Basal, mmol/L & 0.43 & 0.44 & 0.06 & 0.881 \\
\hline Nadir, mmol/L & 0.36 & 0.42 & 0.05 & 0.486 \\
\hline $\mathrm{AUC}_{120 \min },{ }^{2} \mathrm{mmol} / \mathrm{L} \times \min$ & 0.18 & $\begin{array}{l}0.42 \\
1.88\end{array}$ & 1.01 & 0.301 \\
\hline \multicolumn{5}{|l|}{ Epinephrine challenge } \\
\hline \multicolumn{5}{|l|}{ Glucose } \\
\hline Basal, mg/dL & 62.9 & 61.3 & 1.5 & 0.478 \\
\hline Peak, mg/dL & 114 & 104 & 16 & 0.682 \\
\hline $\mathrm{AUC}_{120 \min } \mathrm{mg} / \mathrm{dL} \times \min$ & 900 & 881 & 152 & 0.933 \\
\hline \multicolumn{5}{|l|}{ Nonesterified fatty acids } \\
\hline Basal, $\mathrm{mmol} / \mathrm{L}$ & 0.27 & 0.28 & 0.04 & 0.920 \\
\hline Peak, mmol/L & 0.44 & 0.39 & 0.12 & 0.578 \\
\hline $\mathrm{AUC}_{120 \min }, \mathrm{mmol} / \mathrm{L} \times \min$ & 1.82 & -2.10 & 0.98 & 0.030 \\
\hline \multicolumn{5}{|l|}{ BHB } \\
\hline Basal, mmol/L & 0.47 & 0.46 & 0.06 & 0.925 \\
\hline Peak, mmol/L & 0.49 & 0.57 & 0.13 & 0.441 \\
\hline $\mathrm{AUC}_{120 \min }, \mathrm{mmol} / \mathrm{L} \times \min$ & -1.17 & 1.42 & 0.71 & 0.047 \\
\hline
\end{tabular}

${ }^{1} \mathrm{CR}$ from the peak to $60 \mathrm{~min}=\frac{\ln (\text { glucose at } 5 \mathrm{~min})-\ln (\text { glucose at } 60 \mathrm{~min})}{\min 60-\min 5} \times 100 ; \mathrm{CR}=$ clearance rate.

${ }^{2}$ Area under the curve corrected for the basal levels.

${ }^{3}$ Glucose half life $=\frac{0.693}{\text { glucose clearance rate }} \times 100$.

${ }^{4}$ Insulin stimulated blood glucose response $=\frac{\text { glucose at } 0 \mathrm{~min}-\text { glucose at } 30 \mathrm{~min}}{\text { glucose at } 0 \mathrm{~min}} \times 100$.

after GTT than TN cows fed ad libitum without differences in the insulin response. With similar insulin secretion kinetics during GTT, HS ewes had greater immediate glucose levels than TN ewes, which might be interpreted as decreased insulin sensitivity in HS ewes. This greater available glucose in HS ewes was rapidly taken up, resulting in an increased $(P<0.01)$ glucose clearance rate and a decreased $(P<0.01)$ glucose halflife (Table 4). Glucose is the most efficiently utilized energy source compared with other substrates such as fat or protein (Baldwin et al., 1980), which might explain its fast disappearance in HS conditions. Because of the apparent lack of NEFA availability as a fuel substrate, it seems that heat-stressed animals increase both their production of, and reliance on, glucose as a fuel. As insulin response to GTT did not vary between TN and HS ewes (Table 4), the faster uptake of glucose in HS ewes might have been caused not only by insulin, but also through a non-insulin-mediated glucose uptake process. In fact, the whole-body utilization of 


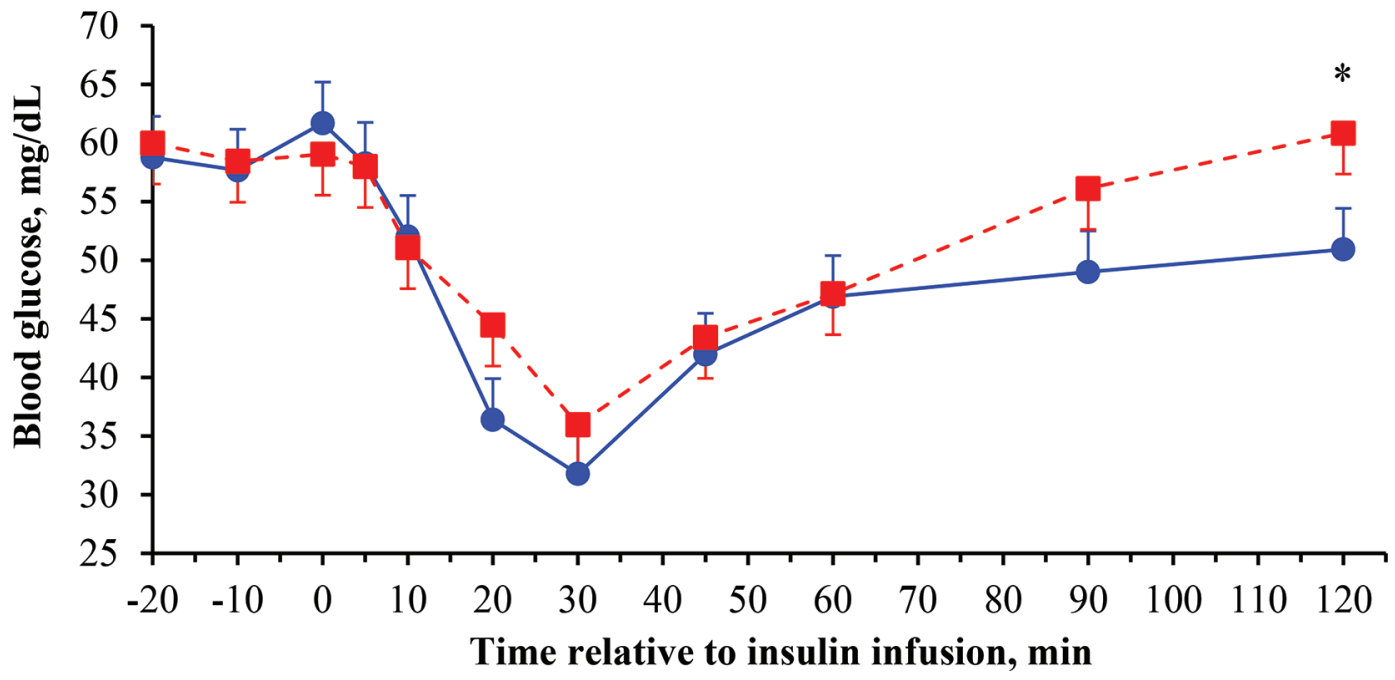

Figure 2. Plasma glucose response to insulin tolerance test of Lacaune dairy ewes under thermoneutral (TN; blue circles) or heat stress (HS; red squares) conditions. Values are means with SE indicated by vertical bars. *Indicates a difference at $P<0.05$ between TN and HS treatments.

glucose can also occur through non-insulin-dependent pathways in crossbred castrated rams (Janes et al., 1985) and Holstein cows (Rose et al., 1997).

Insulin Tolerance Test. Results of the insulin tolerance test as indicator of insulin responsiveness are shown in Figure 2 and Table 4. Plasma glucose concentration in both groups decreased to a nadir at 30 min postinfusion. Thereafter, blood glucose values elevated, and by $120 \mathrm{~min}$ they returned to the basal values in HS ewes, but not in TN $(60.9 \pm 3.5$ vs. 50.9 $\pm 3.4 \mathrm{mg} / \mathrm{dL}$ for TN and HS ewes, respectively; $P<$ 0.05). This result indicated prolonged effect of insulin in TN compared with HS ewes (Figure 2).

However, taking all time points into consideration, insulin AUC and insulin-stimulated blood glucose response did not vary between TN and HS ewes (Table 4), which might be interpreted as unchanged insulin responsiveness. This result agrees with the findings of Achmadi et al. (1993), who found that glucose amount needed to keep euglycemia when insulin is infused do not vary between TN and HS Suffolk ewes. Given the fact that blood glucose did not return to the basal levels by min 120 in TN ewes (Figure 2), it is possible that differences in insulin-responsiveness kinetics would have been detected if sampling time was extended beyond $120 \mathrm{~min}$. Neither plasma NEFA nor BHB concentrations were affected by the insulin infusion, although NEFA AUC was lower in HS than in TN ewes (Table 4). The lower NEFA AUC levels in HS ewes might be related to the increased dependence on glucose as an energy source and the decreased body fat mobilization.
Epinephrine Challenge. Plasma glucose peak in response to the epinephrine challenge was similar between groups (Table 4), but HS ewes had an earlier peak $(5 \mathrm{~min})$ than $\mathrm{TN}$ ewes $(10 \mathrm{~min})$, as shown in Figure 3a. At $10 \mathrm{~min}$, TN ewes had greater $(P<0.05)$ blood glucose $(114 \mathrm{mg} / \mathrm{dL})$ than HS ewes $(99 \mathrm{mg} / \mathrm{dL})$. Similar glucose AUC between TN and HS ewes suggests equal liver sensitivity to epinephrine with regard to breaking down glycogen and releasing glucose.

Blood NEFA levels (Figure 3b) were lower in HS ewes than TN ewes from 30 min after infusion until min 120. The blunted lipolytic response to epinephrine in HS ewes occurred despite the reduced DMI, which is typically associated with elevated circulating NEFA levels. Baumgard et al. (2011) also demonstrated that HS Holstein cows have a reduced NEFA response to epinephrine administration. Epinephrine has been reported to be elevated during HS, especially during the early phase (acute) of hyperthermia (Silanikove, 2000). This elevation could modify the density and affinity of the adrenergic receptors (Mirit et al., 2000), which could explain the increased resistance of adipose tissue to lipolytic signals in HS ewes.

Alternatively, the released NEFA in HS ewes were rapidly taken up by the liver and converted into ketone bodies. This would explain the greater $(P<0.05)$ AUC of BHB (Table 4) in HS compared with that of TN ewes. Salama et al. (2014) proposed that the liver of HS Murciano-Granadina goats is able to uptake NEFA faster, and converts them to BHB (utilized as an energy source for body tissues to spare glucose), when compared with TN goats. 
A

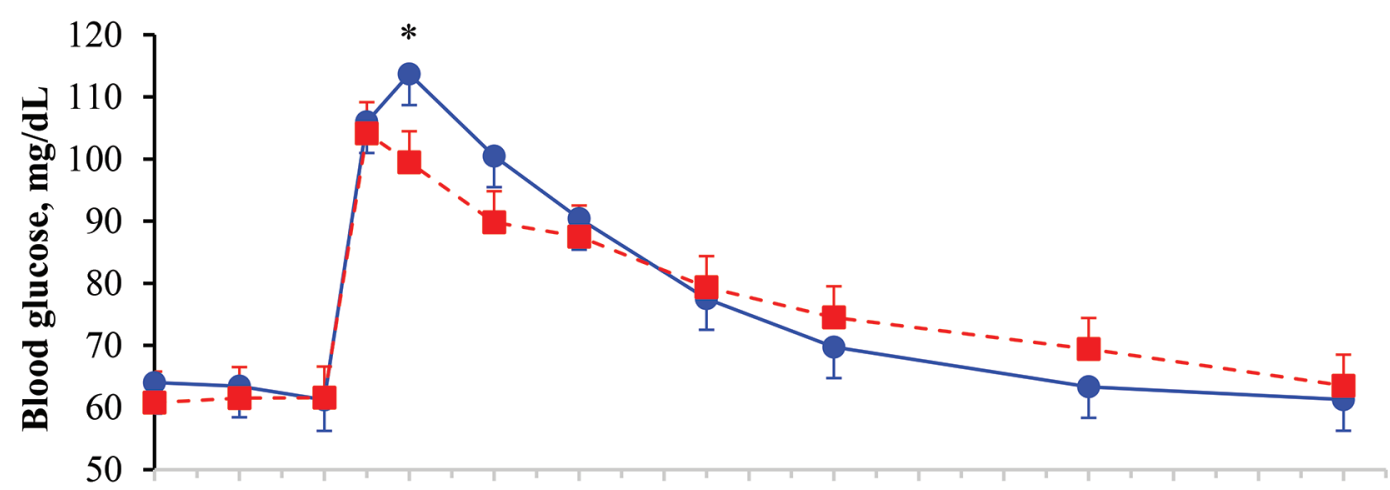

B

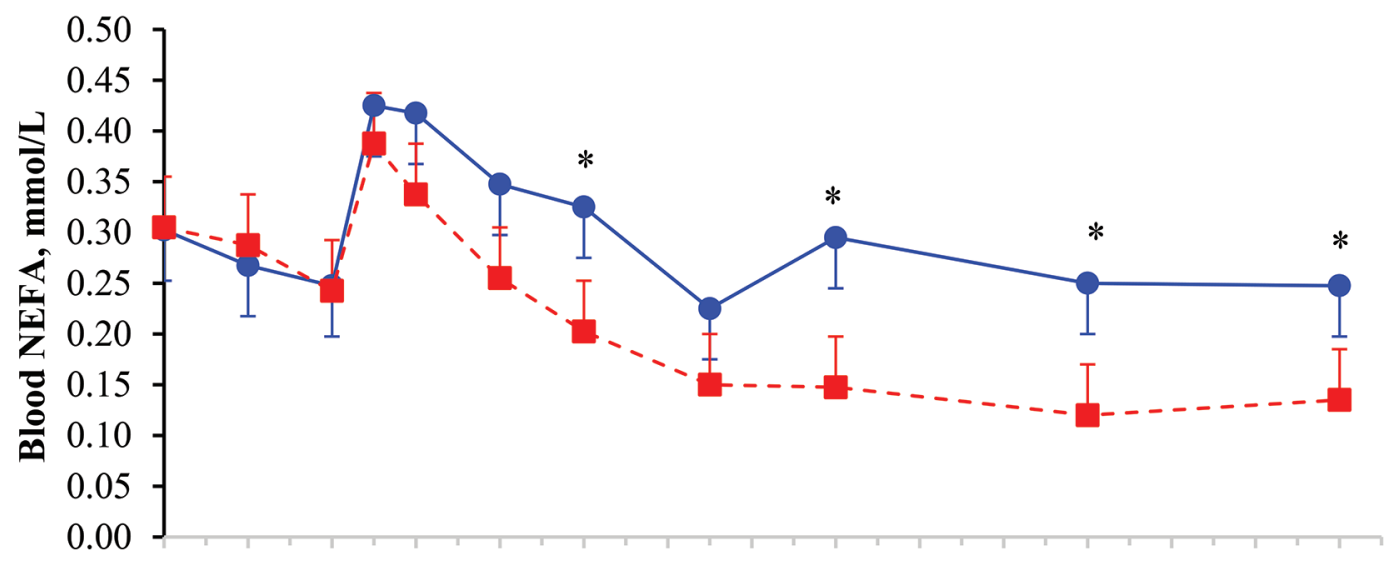

$\mathrm{C}$

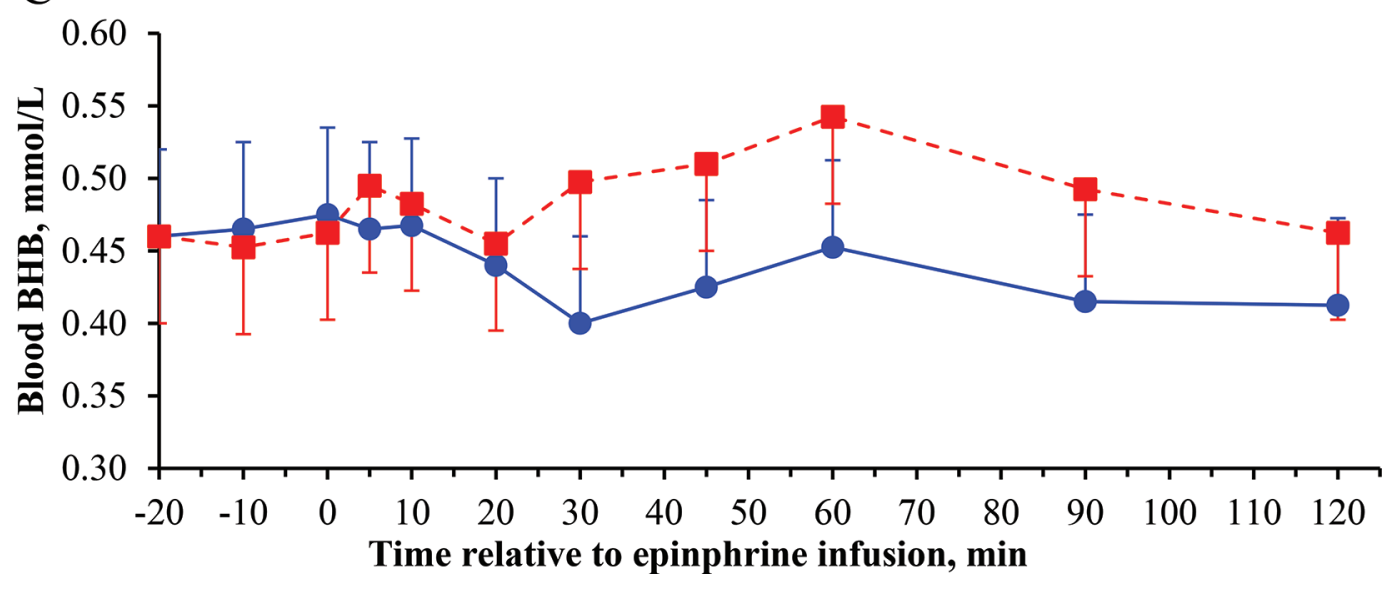

Figure 3. Plasma glucose (A), nonesterified fatty acids (NEFA; B), and BHB (C) response to epinephrine challenge of Lacaune dairy ewes under thermoneutral (TN; blue circles) or heat stress (HS; red squares) conditions. Values are LSM with SE indicated by vertical bars. *Indicates a difference at $P<0.05$ between TN and HS treatments. 


\section{CONCLUSIONS}

Heat stress reduced feed intake, but Lacaune dairy ewes were able to maintain milk yield as well as the yields of fat, protein, and lactose. Heat-stressed ewes did not mobilize body fat reserves, but degraded muscles as indicated by the greater blood creatinine levels. Heat-stressed ewes tended to have more available glucose in the blood after glucose was administered, and it is likely that this glucose was taken up through insulin- and non-insulin-mediated pathways. Further, adipose tissue of HS ewes became more resistant to the lipolytic signals. Overall, these metabolic adaptations allowed dairy ewes to spare glucose and to avoid reductions in milk yield.

\section{ACKNOWLEDGMENTS}

This work is part of 2 research projects funded by the Spanish Ministry of Economy and Competitiveness (AGL2013-44061-R and RTA205-00035-C03-02, Madrid, Spain). Nabil Mehaba received a scholarship from Agency for Management of University and Research Grants (AGAUR, Barcelona, Spain) of the Catalan Government (Reference 2017FI_B 00303). The authors are also grateful to the team of SGCE (Servei de Granges i Camps Experimentals) of the Universitat Autònoma de Barcelona (Barcelona, Spain) for the care of the animals. The authors declare no conflicts of interest.

\section{REFERENCES}

Abdalla, E. B., E. A. Kotby, and H. D. Johnson. 1993. Physiological responses to heat-induced hyperthermia of pregnant and lactating ewes. Small Rumin. Res. 11:125-134. https://doi.org/10.1016/ 0921-4488(93)90145-8.

Achmadi, J., T. Yanagisawa, H. Sano, and Y. Terashima. 1993. Pancreatic insulin secretory response and insulin action in heat-exposed sheep given a concentrate or roughage diet. Domest. Anim. Endocrinol. 10:279-287. https://doi.org/10.1016/0739-7240(93)90032-7.

AOAC International. 2003. Official Methods of Analysis of AOAC International. Vol. I. 17th ed. AOAC International, Gaithersburg, MD.

Baldwin, R. L., N. E. Smith, J. Taylor, and M. Sharp. 1980. Manipulating metabolic parameters to improve growth rate and milk secretion. J. Anim. Sci. 51:1416-1428. https://doi.org/10.2527/ jas1981.5161416x.

Baumgard, L. H., and R. P. Rhoads Jr.. 2013. Effects of heat stress on postabsorptive metabolism and energetics. Annu. Rev. Anim. Biosci. 1:311-337. https://doi.org/10.1146/annurev-animal-031412 $-103644$.

Baumgard, L. H., J. B. Wheelock, S. R. Sanders, C. E. Moore, H. B. Green, M. R. Waldron, and R. P. Rhoads. 2011. Post-absorptive carbohydrate adaptations to heat stress and monensin supplementation in lactating Holstein cows. J. Dairy Sci. 94:5620-5633. https://doi.org/10.3168/jds.2011-4462.

Caroprese, M., M. Albenzio, A. Bruno, V. Fedele, A. Santillo, and A. Sevi. 2011. Effect of solar radiation and flaxseed supplementation on milk production and fatty acid profile of lactating ewes under high ambient temperature. J. Dairy Sci. 94:3856-3867. https://doi .org/10.3168/jds.2010-4067.

Curtis, S. E. 1983. Environmental management in animal agriculture. 2nd ed. Iowa State University, Ames, Iowa.

FAO. 2018. FAOSTAT. Accessed Oct. 1, 2020. http://www.fao.org/ faostat/en/\#data/QA.

Finocchiaro, R., J. B. C. H. M. van Kaam, B. Portolano, and I. Misztal. 2005. Effect of heat stress on production of Mediterranean dairy sheep. J. Dairy Sci. 88:1855-1864. https://doi.org/10.3168/ jds.S0022-0302(05)72860-5.

Hales, J. R., and G. D. Brown. 1974. Net energetic and thermoregulatory efficiency during panting in the sheep. Comp. Biochem. Physiol. A Comp. Physiol. 49(3A):413-422. https://doi.org/10 .1016/0300-9629(74)90557-X.

Hamzaoui, S., A. A. K. Salama, E. Albanell, X. Such, and G. Caja. 2013. Physiological responses and lactational performances of latelactation dairy goats under heat stress conditions. J. Dairy Sci 96:6355-6365. https://doi.org/10.3168/jds.2013-6665.

INRA. 2018. INRA Feeding System for Ruminants. Wageningen Acad. Publ. Wageningen, the Netherlands.

Janes, A. N., T. E. Weekes, and D. G. Armstrong. 1985. Insulin action and glucose metabolism in sheep fed on dried-grass or ground maize-based diets. Br. J. Nutr. 54:459-471. https://doi.org/10 $.1079 / B J N 19850131$.

Kerestes, M., V. Faigl, M. Kulcsar, O. Balogh, J. Foldi, H. Febel, Y. Chilliard, and G. Huszenicza. 2009. Periparturient insulin secretion and whole-body insulin responsiveness in dairy cows showing various forms of ketone pattern with or without puerperal metritis. Domest. Anim. Endocrinol. 37:250-261. https://doi.org/10.1016/j .domaniend.2009.07.003.

Li, G., I. S. Ali, and R. W. Currie. 2006. Insulin induces myocardial protection and HSP70 localization to plasma membranes in rat hearts. Am. J. Physiol. Heart Circ. Physiol. 291:H1709-H1721. https://doi.org/10.1152/ajpheart.00201.2006.

Mehaba, N., A. A. K. Salama, X. Such, E. Albanell, and G. Caja. 2019. Lactational responses of heat-stressed dairy goats to dietary L-carnitine supplementation. Animals (Basel) 9:567. https://doi .org/10.3390/ani9080567.

Mirit, E., C. Gross, Y. Hasin, A. Palmon, and M. Horowitz. 2000. Changes in cardiac mechanics with heat acclimation: adrenergic signaling and SR-Ca regulatory proteins. Am. J. Physiol. Regul. Integr. Comp. Physiol. 279:R77-85. https://doi.org/10.1152/ ajpregu.2000.279.1.R77.

Murphy, T. W., W. C. Stewart, and J. B. Taylor. 2018. Factors affecting ewe somatic cell count and its relationship with lamb weaning weight in extensively managed flocks. Transl. Anim. Sci. 2(Suppl. 1):S159-S162. https://doi.org/10.1093/tas/txy031.

NRC. 1971. A Guide to Environmental Research on Animals. National Academy of Sciences, Washington, DC.

NRC. 2001. Nutrient Requirements of Dairy Cattle. 7th ed. National Academy of Sciences, Washington, DC.

Okoruwa, M. I. 2014. Effect of heat stress on thermoregulatory, live body weight and physiological responses of dwarf goats in southern Nigeria. Eur. Sci. J. 10:255-264.

Olsson, K., and K. Dahlborn. 1989. Fluid balance during heat stress in lactating goats. Q. J. Exp. Physiol. 74:645-659. https://doi.org/10 .1113/expphysiol.1989.sp003317.

Pasqui, M., and E. Di Giuseppe. 2019. Climate change, future warming, and adaptation in Europe. Anim. Front. 9:6-11. https://doi .org/10.1093/af/vfy036.

Peana, I., G. Fois, and A. Cannas. 2007. Effects of heat stress and diet on milk production and feed and energy intake of Sarda ewes. Ital. J. Anim. Sci. 6(sup1):577-579. https://doi.org/10.4081/ijas .2007.1s.577.

Pulina, G., N. Macciotta, and A. Nudda. 2005. Milk composition and feeding in the Italian dairy sheep. Ital. J. Anim. Sci. 4(sup1):5-14. https://doi.org/10.4081/ijas.2005.1s.5.

Ramón, M., C. Diaz, M. D. Perez-Guzman, and M. J. Carabaño. 2016. Effect of exposure to adverse climatic conditions on production in Manchega dairy sheep. J. Dairy Sci. 99:5764-5779. https://doi .org/10.3168/jds.2016-10909. 
Ronchi, B., U. Bernabucci, N. Lacetera, A. Verini Supplizi, and A. Nardone. 1999. Distinct and common effects of heat stress and restricted feeding on metabolic status in Holstein heifers. Zootec. Nutr. Anim. 25:11-20.

Rose, M. T., Y. Obara, F. Itoh, H. Hashimoto, and Y. Takahashi. 1997. Non-insulin- and insulin-mediated glucose uptake in dairy cows. J. Dairy Res. 64:341-353. https://doi.org/10.1017/ S0022029997002215.

Salama, A. A. K., G. Caja, E. Albanell, X. Such, R. Casals, and J. Plaixats. 2003. Effects of dietary supplements of zinc methionine on milk production, udder health and zinc metabolism in dairy goats. J. Dairy Res. 70:9-17. https://doi.org/10.1017/ S0022029902005708.

Salama, A. A. K., G. Caja, S. Hamzaoui, B. Badaoui, A. CastroCosta, D. A. E. Façanha, M. M. Guilhermino, and R. Bozzi. 2014. Different levels of response to heat stress in dairy goats. Small Rumin. Res. 121:73-79. https://doi.org/10.1016/j.smallrumres.2013 .11 .021 .

Salama, A. A. K., M. Duque, L. Wang, K. Shahzad, M. Olivera, and J. J. Loor. 2019. Enhanced supply of methionine or arginine alters mechanistic target of rapamycin signaling proteins, messenger RNA, and microRNA abundance in heat-stressed bovine mammary epithelial cells in vitro. J. Dairy Sci. 102:2469-2480. https:/ /doi.org/10.3168/jds.2018-15219.

Sevi, A., G. Annicchiarico, M. Albenzio, L. Taibi, A. Muscio, and S. Dell'Aquila. 2001. Effects of solar radiation and feeding time on behavior, immune response and production of lactating ewes under high ambient temperature. J. Dairy Sci. 84:629-640. https://doi .org/10.3168/jds.S0022-0302(01)74518-3.

Silanikove, N. 1992. Effects of water scarcity and hot environment on appetite and digestion in ruminants: A review. Livest. Prod. Sci. 30:175-194. https://doi.org/10.1016/S0301-6226(06)80009-6.
Silanikove, N. 2000. Effects of heat stress on the welfare of extensively managed domestic ruminants. Livest. Prod. Sci. 67:1-18. https:// doi.org/10.1016/S0301-6226(00)00162-7.

Singh, K. M., S. Singh, I. Ganguly, A. Ganguly, R. K. Nachiappan, A. Chopra, and H. K. Narula. 2016. Evaluation of Indian sheep breeds of arid zone under heat stress condition. Small Rumin. Res. 141:113-117. https://doi.org/10.1016/j.smallrumres.2016.07.008.

Stelwagen, K., H. Hopster, J. T. N. Van Der Werf, and H. J. Blokhuis . 2000. Effects of isolation stress on mammary tight junctions in lactating dairy cows. J. Dairy Sci. 83:48-51. https://doi.org/10 .3168/jds.S0022-0302(00)74853-3.

Thompson, G. E., P. E. Hartmann, J. A. Goode, and K. S. Lindsay. 1981. Some effects of acute fasting and climatic stresses upon milk secretion in Friesland sheep. Comp. Biochem. Physiol. A Physiol. 70:13-16. https://doi.org/10.1016/0300-9629(81)90385-6.

Wheelock, J. B., R. P. Rhoads, M. J. Vanbaale, S. R. Sanders, and L. H. Baumgard. 2010. Effects of heat stress on energetic metabolism in lactating Holstein cows. J. Dairy Sci. 93:644-655. https://doi .org/10.3168/jds.2009-2295.

\section{ORCIDS}

Nabil Mehaba ( https://orcid.org/0000-0002-1701-5407

Wellington Coloma-Garcia @ https://orcid.org/0000-0003-3182-2085

Xavier Such @ ittps://orcid.org/0000-0002-9712-4477

Gerardo Caja ® https://orcid.org/0000-0001-8606-3587

Ahmed A. K. Salama @ https://orcid.org/0000-0003-2065-9702 